\title{
ПОЛУЧЕНИЕ И ФИЗИКО-ХИМИЧЕСКИЕ СВОЙСТВА ДИАЛЬДЕГИДДЕКСТРАНА
}

\section{Ю.И. Пристромова, Т.Л. Юркштович, Н.В. Голуб, Р.И. Костерова, С.О. Соломевич}

\author{
Научно-исследовательский институт физико-химических проблем \\ белорусского государственного университета, \\ 220030, Республика Беларусь, Минск, ул. Ленинградская, 14.
}

DOI: 10.19163/MedChemRussia2021-2021-517

E-mail: prystromyi@gmail.com

Диальдегиддекстран (ДАД) широко применяется в медицине и фармацевтической промышленности для разработки новых пролонгированных форм лекарственных веществ благодаря низкой токсичности, биосовместимости, а также способности ковалентно связывать и контролированно высвобождать различные биологически активные вещества, содержащие первичные аминогруппы. Цель данной работы - получение образцов ДАД с разным содержанием альдегидных групп, изучение влияния условий синтеза на содержание альдегидных групп и физико-химические свойства ДАД.

В качестве исходного материала использовали декстран с молекулярной массой 60 кДа. Гомофазное окисление полисахарида проводили в водном растворе иодата натрия разной концентрации.

Изучено влияние мольного соотношения $\mathrm{NaJO}_{4}$ : D-глюкопиранозное звено (ГПЗ) в интервале 0,06-1,5, времени (5-1440 мин), температуры реакции $\left(0-30^{\circ} \mathrm{C}\right)$, а также $\mathrm{pH}$ реакционной среды $(2,6-6,9)$ на состав, скорость растворения и гидролитическую устойчивость окисленных образцов декстрана в условиях in vitro. Получены образцы ДАД, степень окисления которых, рассчитанная как число окисленных звеньев на 100 ГПЗ, находится в интервале значений 15-41. Показано, что наряду с накоплением альдегидных групп в составе декстрана протекает побочный процесс деструкции полисахаридов.

Установлено, что по мере роста содержания альдегидных групп в составе декстрана скорость растворения образцов ДАД уменьшается. Проведен термогравиметрический анализ исходного декстрана и образцов ДАД с различной степенью окисления и установлено что, по мере увеличения содержания альдегидных групп в ДАД термическая стабильность образцов уменшается.

Проведена оценка гидролитической деструкции in vitro образцов исходного и окисленного декстрана в буферных растворах с $\mathrm{pH}$ 2.0, 3.5 и 7,4. Установлено, что наиболее гидролитически устойчивы образцы ДАД в буферном растворе с рН 3.5. Наиболее высокая скорость химического гидролиза наблюдается в фосфатном буферном растворе с $\mathrm{pH}$ 7.4. При $\mathrm{pH}$ буферного раствора 2,0 скорость реакции, ее глубина зависит от содержания альдегидных групп в образцах ДАД и увеличиваются по мере их роста. 